\title{
Gasification of plastic waste as waste-to-energy or waste-to-syngas recovery route
}

\author{
Anke Brems $^{1^{*}}$, Raf Dewil ${ }^{1}$, Jan Baeyens ${ }^{2}$, Rui Zhang ${ }^{2}$ \\ ${ }^{1}$ Department of Chemical Engineering, Chemical and Biochemical Process Technology and Control Section, Katholieke Universiteit \\ Leuven, Heverlee, Belgium; 'Corresponding Author: anke.brems@cit.kuleuven.be \\ ${ }^{2}$ College of Life Science and Technology, The Key Laboratory of Bioprocess of Beijing, Beijing University of Chemical Technology, \\ Beijing, China
}

Received 19 December 2012; revised 25 March 2013; accepted 2 April 2013

Copyright (C) 2013 Anke Brems et al. This is an open access article distributed under the Creative Commons Attribution License, which permits unrestricted use, distribution, and reproduction in any medium, provided the original work is properly cited.

\section{ABSTRACT}

The disposal of plastic solid waste (PSW) has become a major worldwide environmental problem. New sustainable processes have emerged, i.e. either advanced mechanical recycling of PSW as virgin or second grade plastic feedstock, or thermal treatments to recycle the waste as virgin monomer, as synthetic fuel gas, or as heat source (incineration with energy recovery). These processes avoid land filling, where the non-biodegradable plastics remain a lasting environmental burden. Within the thermal treatments, gasification and pyrolysis gain increased interest. Gasification has been widely studied and applied for biomass and coal, with results reported and published in literature. The application to the treatment of PSW is less documented. Gasification is commonly operated at high temperatures $\left(>600^{\circ} \mathrm{C}\right.$ to $\left.800^{\circ} \mathrm{C}\right)$ in an airlean environment (or oxygen-deficient in some applications): the air factor is generally between $20 \%$ and $40 \%$ of the amount of air needed for the combustion of the PSW. Gasification produces mostly a gas phase and a solid residue (char and ashes). The use of air introduces $\mathrm{N}_{2}$ in the product gases, thus considerably reducing the calorific value of the syngas, because of the dilution. The paper will review the existing literature data on PSW gasification, both as the result of laboratory and pilot-scale research. Processes developed in the past will be illustrated. Recently, the use of a sequential gasification and combustion system (at very high temperatures) has been applied to various plastic-containing wastes, with atmospheric emissions shown to be invariably below the legal limits.
Operating results and conditions will be reviewed in the paper, and completed with recent own lab-scale experimental results. These results demonstrate that gasification of PSW can be considered as a first order reaction, with values of the activation energy in the order of 187 to $289 \mathrm{~kJ} / \mathrm{mol}$ as a function of the PSW nature.

Keywords: Plastic Waste; Re-Use; Gasification; Syngas; Char; Sustainability; Reaction Rate

\section{INTRODUCTION: PSW AND ITS TREATMENT OPTIONS}

Plastics are light-weight, durable, and versatile, allowing their incorporation into a diverse range of applications. In recent years, the environmental, social and economic impact of plastics has been the topic of the political agenda, with a focus on sustainable production and the decoupling of adverse environmental effects from waste generation. The disposal of waste plastics has become a major worldwide environmental problem. The USA, Europe and Japan generate about 55 million tons of post consumer plastic waste [1]. These waste products were previously dumped in landfill sites, a non-sustainable and environmentally questionable option. The number of landfill sites and their capacity are moreover decreasing rapidly and in most countries the legislation on landfills is becoming increasingly stringent.

New sustainable processes have emerged, i.e. 1) the advanced mechanical recycling of post-consumer plastic waste as virgin or second grade plastic feedstock; and 2) thermal treatments to recycle the waste as virgin monomer, as synthetic fuel gas, as hydrocarbon feedstock, or as a heat source (incineration with energy recovery). These processes avoid land filling, where the non-biodegradable plastics remain a lasting environmental bur- 
den. Plastic solid waste (PSW) treatment can be divided in four methods, as illustrated in Figure 1, each individual method providing a unique set of advantages making it particularly suited and beneficial to a specific location, application or product requirement [2,3]. The purpose of recycling is to minimize the consumption of finite natural resources, and this is especially relevant in the case of plastics which account for the use of $4 \%-8 \%$ of the global oil production [3]: re-using plastics is the required course of action, with the additional benefit of reducing emissions associated with plastic production [3]. The most appropriate recovery method is chosen considering the environmental, economic and social impact of a particular technique. Figure 1 illustrates the position of each recycling method within the production chain.

\section{THERMO-CHEMICAL RECYCLING OF PSW}

Thermo-chemical recycling refers to advanced technology processes which convert plastic materials into smaller molecules, usually liquids or gases, which are suitable for use as a feedstock for the production of new petrochemicals and plastics [1]. Products have moreover been proven to be useful as fuel. The technology behind its success is the de-polymerisation process that can result in a very profitable and sustainable industrial scheme, providing a high product yield and a minimum residual waste. Processes of pyrolysis, gasification, hydrogen-nation, and steam/catalytic cracking have been previously reported upon [1].

Recently, much attention has been paid to chemical recycling (mainly pyrolysis, gasification and catalytic degradation) as a method of producing various hydrocarbon fractions from PSW. By their nature, a number of polymers are advantageous for such treatment. Thermolysis is the treatment of PSW in the presence of heat at controlled temperatures and under a controlled environment. Thermolysis processes can be divided into pyrolysis (thermal cracking in an inert atmosphere), gasification (in the sub-stoichiometric presence of air usually leading to $\mathrm{CO}$ and $\mathrm{CO}_{2}$ production) and hydrogenation (hydrocracking) [4].

Pyrolysis can be successfully applied to Polyethylene teraphthalate (PET), polystyrene (PS), polymethylmetacrylate (PMMA) and certain polyamides such as nylon, efficiently depolymerising them into constitutive monomers [5-7]. Polyolefins, and in particular polyethylene $(\mathrm{PE})$, has been targeted as a potential pyrolysis feedstock for fuel (gasoline) production, or to produce waxes as feedstock for synthetic lubricants, albeit with a limited success.

The development of value added recycling technologies is highly desirable as it would increase the economic incentive to recycle polymers. Several methods for thermochemical recycling are presently in use, such as direct gasification, and degradation by liquefaction [8]. Various degradation methods for obtaining petrochemicals are presently under investigation, and conditions suitable for pyrolysis and gasification are being researched extensively [9].

Catalytic cracking and reforming facilitate the selective degradation of waste plastics. The use of solid catalysts such as silica-alumina, ZSM-5 or zeolites, effect tively converts polyolefins into liquid fuel, giving lighter fractions as compared to thermal cracking.

Gasification has recently been attracting increased attention as thermo-chemical recycling technique. Its main advantage is the possibility of treating heterogeneous and

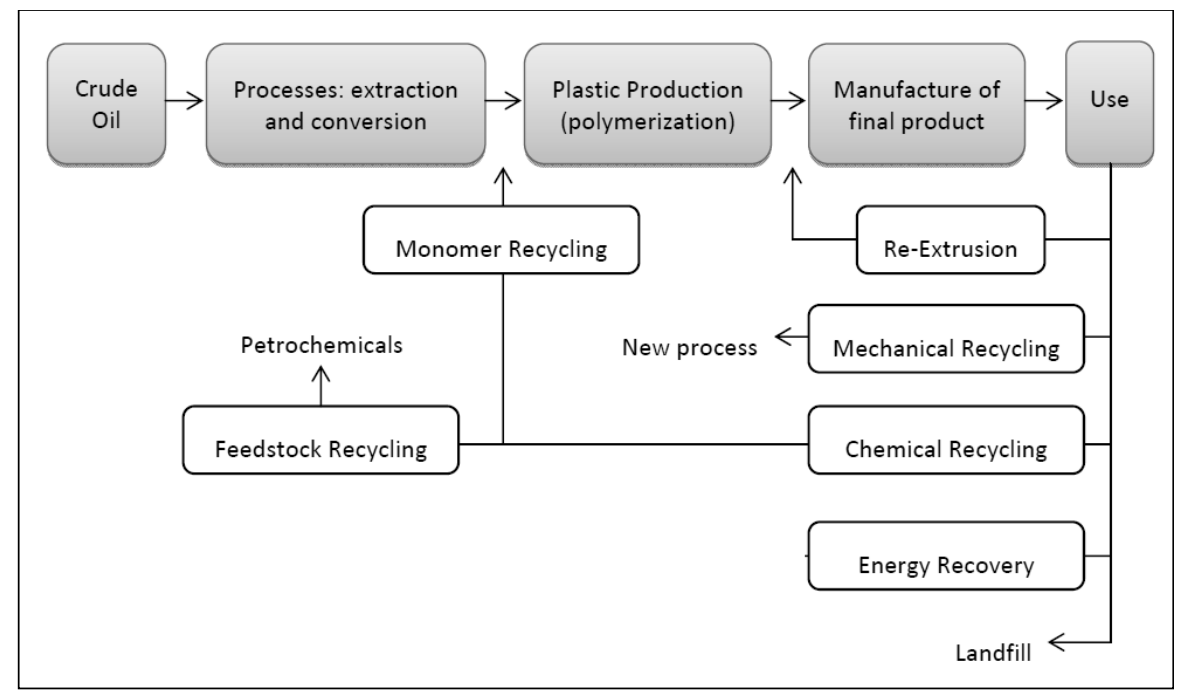

Figure 1. Schematic of recycling methods and their position within the processing line (Adapted from [2]). 
contaminated polymers with limited use of pre-treatment, whilst the production of syngas creates different applications in synthesis reactions or energy utilisation. Gasification has been widely studied and applied for biomass and coal, with results reported and published in literature. The application for the treatment of plastic solid waste is less documented, although the number of publications increases exponentially.

Figure 2 shows different thermolysis schemes, main technologies and their main products obtained, as initially presented by Mastellone [10].

\section{GASIFICATION}

\subsection{Gasification of PSW}

Gasification or partial oxidation of plastic waste is commonly operated at high temperatures $\left(>600^{\circ} \mathrm{C}-800^{\circ} \mathrm{C}\right)$. Air (or oxygen in some applications) is used as a gasification agent, and the air factor is generally $20 \%-40 \%$ of the amount of air needed for the combustion of the PSW. The process essentially oxidizes the hydrocarbon feedstock in a controlled fashion to generate the endothermic depolymerisation heat. The primary product is a gaseous mixture of carbon monoxide and hydrogen, with minor percentages of gaseous hydrocarbons also formed. This gas mixture is known as syngas and can be used as a substitute for natural gas or in the chemical industry as feedstock for the production of numerous chemicals. For most of the PSW components, the ash and char production is limited [3,11-13].

A hydrogen production efficiency of $60 \%-70 \%$ from polymer waste has been reported [14]. Gasification is an attractive alternative to direct incineration of PSW, since it reduces the formation of dioxins and aromatic compounds.

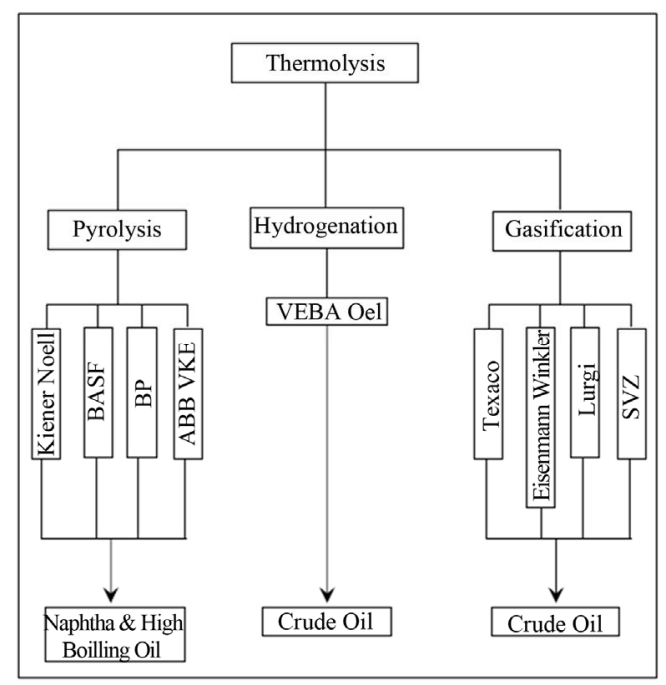

Figure 2. Different thermolysis schemes with reference to the main technologies [10].
Gasification efficiently utilizes the chemical energy and recoverable raw materials inherent in unsorted domestic waste, industrial and special waste (e.g. medical waste), and is capable of transforming almost all of the total waste input into technically usable raw materials and energy [12].

Co-gasification of biomass with polymers has also been shown to increase the amount of hydrogen produced while the $\mathrm{CO}$ content is reduced [15].

A $40 \mathrm{MW}$ fluidized bed gasifier has been installed by Corenso in Varkaus (Finland) for processing polyethylene plastics with metallic aluminium recovery from recycling of Tetrapak cartons.

A typical circulating fluidized bed gasifier is illustrated in Figure 3, with the syngas being thermally used in a boiler arrangement [16].

Air is mostly used as a gasification agent: the main advantage of using air instead of $\mathrm{O}_{2}$ alone is to simplify the process and reduce the cost. But a disadvantage is $\mathrm{N}_{2}$ being present causing the reduction in the calorific value of resulting syngas due to the dilution.

Several types of gasification processes have previously been developed and reported. Their practical performance data, however, have not necessarily been satisfactory for universal application. If char is produced in the gasification, it needs to be further processed and/or burnt. Other gasification schemes (mainly in pilot scale) use a great deal of expensive pure oxygen, whilst others necessitate considerable amounts of expensive materials such as coke and limestone. An ideal gasification process for PSW should produce a high calorific value gas, completely combusted char, produce an easily recoverable ash and should not require any additional installations for air/water pollution abatement.

Early gasification attempts of plastics present in municipal solid waste have been reported since the 1970s $[17,18]$. The gasification with high calorific value fuel gas obtained from PSW was demonstrated in research stages and results were reported and published in literature for PVC [19], PP [20] and PET [21]. The need for alternative fuels has lead for the co-gasification of PSW with other types of waste, mainly biomass. Pinto et al. $[15,22]$ studied the fluidized bed co-gasification of PE, pine and coal and biomass mixed with PE. Slapak et al. [23] designed a process for steam gasification of PVC in a bubbling fluidized bed.

Xiao et al. [24] co-gasified five typical kinds of organic components (wood, paper, kitchen waste, PE-plastic, and textile) and three representative types of simulated municipal solid waste (MSW) in a fluidized-bed $\left(400^{\circ} \mathrm{C}\right.$ $800^{\circ} \mathrm{C}$ ). It was determined that plastic should be gasified at temperatures in excess of $500^{\circ} \mathrm{C}$ to reach a lower heating value (LHV) of $10,000 \mathrm{~kJ} / \mathrm{Nm}^{3}$. Figure 4 represents the process of co-gasification used in their study. 


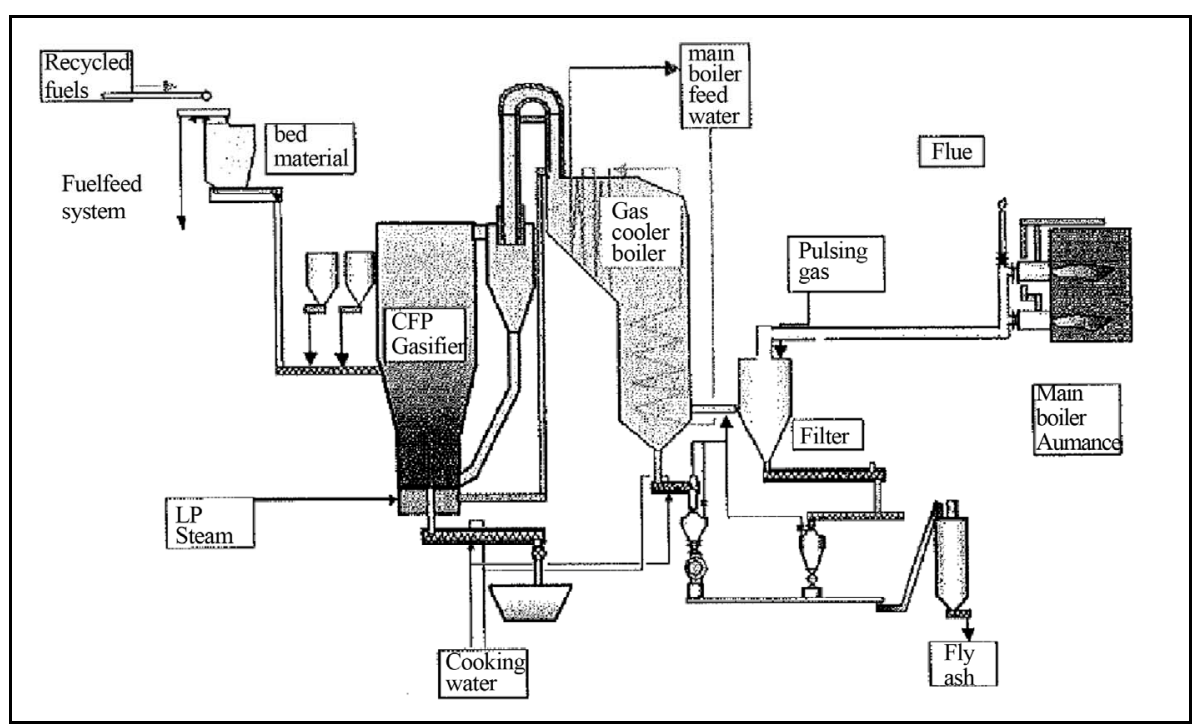

Figure 3. Fluidized bed gasification plant [16].

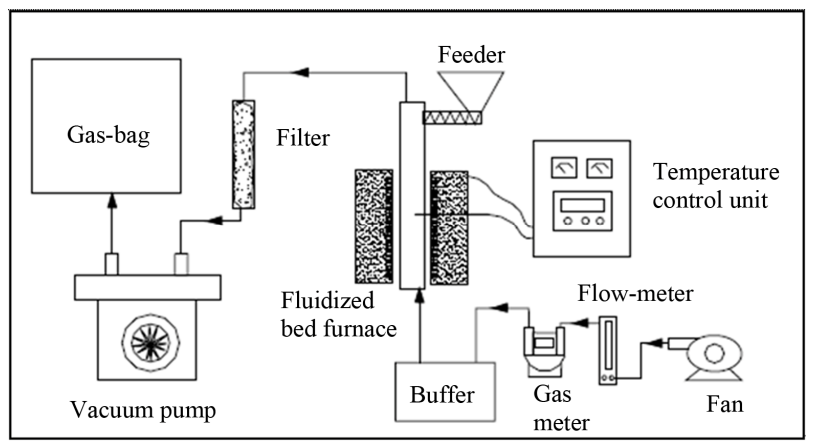

Figure 4. Illustration of the Xiao et al. [24] fluidized bed gasifier.

Gasification produces three different phases: a solid phase (char), a liquid phase (tars) and a gas phase [25]. First products yielded are usually in the range of $\mathrm{C}_{20}$ to $\mathrm{C}_{50}$. These products are cracked in the gas phase to obtain lighter hydrocarbons, as ethene and propene, which are unstable at high temperatures and react to form aromatic compounds as benzene or toluene. In thermo-chemical treatment of polyolefins (mainly PE and PP), products obtained mainly depend on cracking reactions in the gas phase. Long residence time of volatiles in reactors and high temperatures decreases tar production but increases char formation [26].

It is believed that increasing temperatures above $500^{\circ} \mathrm{C}$ and prolonging gas residence time, reduces the tar content in the gas product from gasification of PSW, ASR, MSW and even mixtures of coal, biomass and PSW [22, 27-30].

At temperatures above $800^{\circ} \mathrm{C}$, larger paraffins and olefins produced from decomposition of plastics are cracked into $\mathrm{H}_{2}, \mathrm{CO}, \mathrm{CO}_{2}, \mathrm{CH}_{4}$ and lighter hydrocarbons [31].

In PSW gasification, the endothermic gasification re- actions involving steam and $\mathrm{CO}_{2}[32,33]$ (and high heating rates create a char which is more reactive and easier to deal with $[34,35]$. As a result of these reactions, high gasification temperatures have been reported to increase the $\mathrm{H}_{2}$ concentration, gas yield [15] and sometimes LHV [36] for a wide range of gasification configurations and oxidizing media.

\subsection{Gasification of Automotive Shredder Residue (ASR)}

A specific and recent development involves the gasification of ASR, where plastics are significantly present.

The study of Harder and Forton [37] describes the process developed by Schwarze Pumpe, producing methanol as a fuel. Sequential gasification and incineration tests were reported by Mancini et al. [38] and make use of a rotary kiln operated between $850^{\circ} \mathrm{C}$ and $1120^{\circ} \mathrm{C}$ with an air factor $<1$. Combustion of the gases is completed in a secondary afterburner chamber. The system includes a boiler (steam at $43 \mathrm{bar}, 430^{\circ} \mathrm{C}$ ) and turbine. The capacity was on average $2400 \mathrm{~kg} / \mathrm{h}$ during the tests. The paper fully describes the characteristics of the ASR used, the combustion properties, the ash analyses, the composition of the exhaust gases, the process operational problems, the residue management, and the energy efficiency. It was concluded that the process requires minor modifications. Atmospheric emissions were invariably considerably below the legal limits.

A similar full report of a sequential gasification and combustion unit to treat ASR, using a fluidized bed gasifier $\left(590^{\circ} \mathrm{C}\right)$ followed by a cyclonic afterburner $\left(1400^{\circ} \mathrm{C}\right)$ is described by Viganò et al. [39] and by Cho et al. [40]. All operational details and properties of the different process streams are included in the publications. Opera- 
tion of the afterburner at $1400^{\circ} \mathrm{C}$ moreover produces a vitrified (and hence inert) slag. It is concluded that the sequential gasification and combustion system reaches appealing energy and environmental performances, despite the unfavourable characteristics of ASR.

A catalytic gasification of ASR with hydrogen generation is presented by Lin et al. [41], using a lab-scale fixed-bed downdraft gasification process. A $15 \mathrm{wt} \%$ $\mathrm{NiO} / \mathrm{Al}_{2} \mathrm{O}_{3}$ catalyst is used at $760^{\circ} \mathrm{C}-900^{\circ} \mathrm{C}$. It is predicted that such a process, conducted at 46.2 atm would yield $87 \%$ of syngas, with a $0.27 \mathrm{~m}^{3}$ reactor allowing to ultimately produce $100 \mathrm{~kW}$ of electricity starting from $220 \mathrm{~kg} / \mathrm{h}$ of ASR. Further tests are however needed.

Sequential microwave pyrolysis and high temperature agent gasification (HTAG) experiments were performed by Donaj et al. [42,43]. The research suggests using the liquid and solid residue from the microwave pyrolysis as fuel for the HTAG process. In this process a gasifying agent (steam, air or an air/steam mixture) is heated to temperatures above $900^{\circ} \mathrm{C}$, providing all the heat needed for gasification. The use of HTAG can lead to higher conversion of fuel to gas, higher hydrogen yields and lower tar content in comparison to conventional gasification $[42,43]$. Although the results are fairly supportive for the gasification of the liquid pyrolysis residue, additional process optimization is required towards the pyrolysis of the solid residue.

The use of a sequential gasification and combustion system (at very high temperatures) as reported by Mancini et al. [38], by Viganò et al. [39] and by Cho et al. [40] demonstrates that atmospheric emissions were considerably below the legal limits. In the specific Japanese case, the operation of the afterburner at $1400^{\circ} \mathrm{C}$ moreover produces a vitrified (and hence inert) slag. It is concluded that the sequential gasification and combustion system reaches appealing energy and environmental performances, despite the unfavourable characteristics of ASR.

\subsection{Large-Scale Gasification Technologies}

One of the most common technologies is the Waste Gas Technology UK Limited (WGT) process (Figure 5). Different kinds of wastes (PSW, MSW, sludges, rubbers, wood and straw) are dried and mechanically pre-treated, sorting out incombustibles and granulated to optimum sized particles and fed into a cylindrical reactor for gasification at $700^{\circ} \mathrm{C}-900^{\circ} \mathrm{C}$ to yield a $\mathrm{HCV}$ gas [44]. Upon discharge and subsequent separation of gas and char, the latter may be utilized via combustion in a boiler to raise steam while the gas is quenched and cleaned of contaminants prior to its use in a gas engine or turbine and possibly CCGT applications.

The Texaco gasification process is by far the most common and well known technology. First pilot scale experiments (10 tons/day) were carried out in the US [45]. Figure 6 reviews the process which consists of two parts, a liquefaction step and an entrained bed gasifier. In the liquefaction step the plastic waste is mildly thermally cracked (depolymerisation) into synthetic heavy oil and some condensable and non-condensable gas fractions. The non-condensable gases are reused in the liquefaction as fuel (together with natural gas). Oil and condensed gas produced are injected to the entrained gasifier [46]. The gasification is carried out with oxygen and steam at a temperature of $1200^{\circ} \mathrm{C}-1500^{\circ} \mathrm{C}$. After a number of cleaning processes (amongst others, $\mathrm{HCl}$ and $\mathrm{HF}$ removal), a clean and dry synthesis gas is produced, consisting predominantly of $\mathrm{CO}$ and $\mathrm{H}_{2}$, with smaller amounts of $\mathrm{CH}_{4}, \mathrm{CO}_{2}, \mathrm{H}_{2} \mathrm{O}$ and some inert gases [47]. Table 1 summarizes the products from the input criteria and process.

In the case of PSW severely contaminated with other waste products (including contaminated wood, waste water purification sludge, waste derived fuel, paper fractions, etc.), the SVZ process constitutes the optimum solution. The input is fed into a reactor (kiln), together

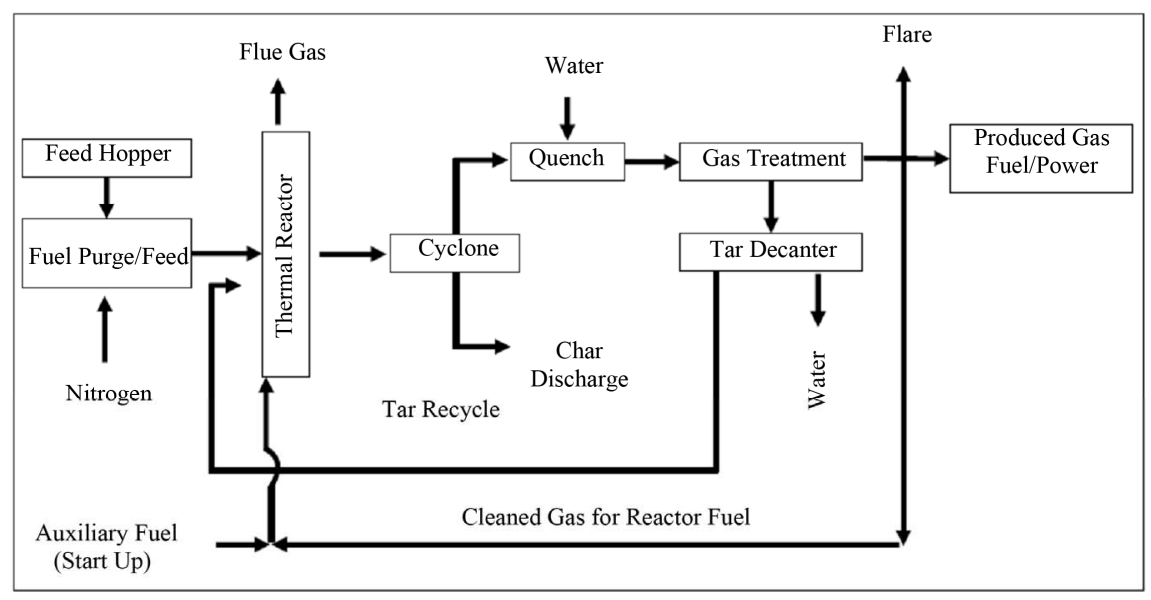

Figure 5. WGT process schematic [44]. 


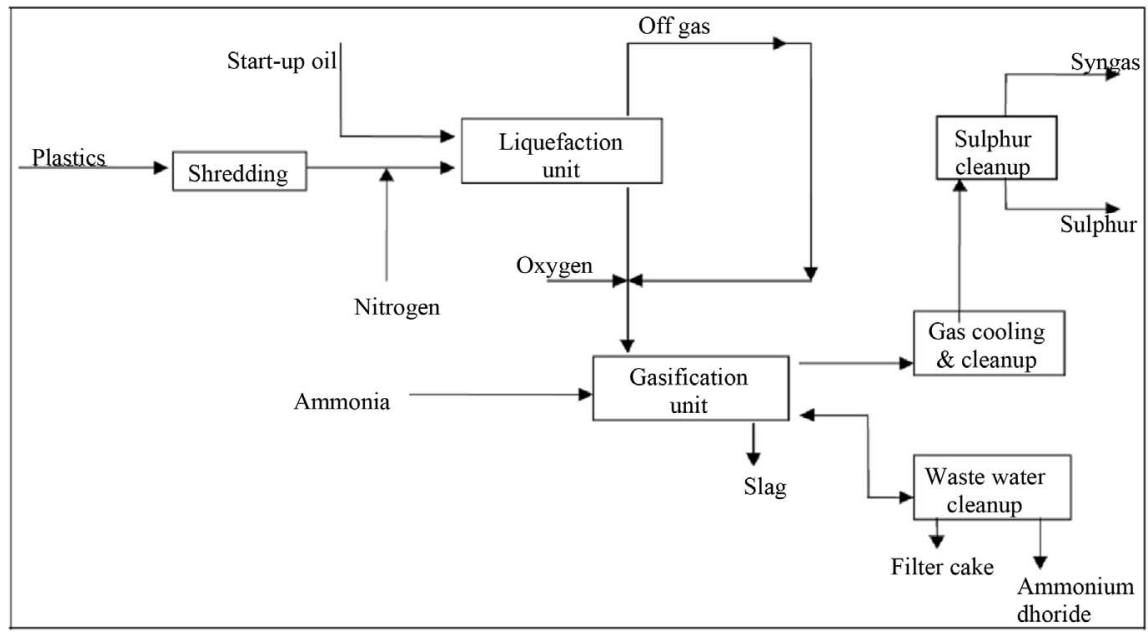

Figure 6. Texaco gasification process schematic diagram, showing both stages involved (liquefaction and gasification) [45].

Table 1. Input criteria and expected output for the Texaco gasification process [47].

\begin{tabular}{|c|c|}
\hline \multicolumn{2}{|r|}{ Input criteria } \\
\hline Feedstock & $\begin{array}{l}\text { Dry to the touch, not sticky, shredded or } \\
\text { chipped to }<10 \mathrm{~cm} \text {, with }<1 \% \text { under } 250 \mu \mathrm{m}\end{array}$ \\
\hline PSW content & $>90 \mathrm{wt} \%$ \\
\hline Free metals & $<1 \mathrm{wt} \%$ \\
\hline PVC content & $<10 \mathrm{wt}^{0} \%$ \\
\hline Ash content & $<6 \mathrm{wt} \%$ \\
\hline Residual moisture & $<5 \mathrm{wt} \%$ \\
\hline Paper content & $<10 \mathrm{wt} \%$ \\
\hline \multicolumn{2}{|r|}{ Expected products } \\
\hline Synthesis gas & $\begin{array}{c}350,000 \mathrm{Nm}^{3} / \text { day (predominantly } \mathrm{H}_{2} / \mathrm{CO} \text { ) out of } \\
150 \text { tonnes of PSW/day }\end{array}$ \\
\hline Vitrified slag & - \\
\hline Fines & High quality, equivalent to fly ash \\
\hline
\end{tabular}

with lignite (in the form of briquettes) and waste oil. Oxygen and steam are used as gasification media, and are supplied in counter flow with the input materials [47]. This processes synthesis gas (a mixture of hydrogen and $\mathrm{CO}$ ), liquid hydrocarbons, and effluent. The gas is used mainly for methanol production and around $20 \%$ is used for electricity production. One of the main advantages of this process is its tolerance for various input parameters. Tukker et al. [47] stated a number of acceptance criteria for the SVZ process, summarized below:

- Particle size: $>20$ to $80 \mathrm{~mm}$;

- Chlorine content: $2 \%$ as default, though higher concentrations are tolerable;

- Ash content: up to $10 \%$ or more.

As a producer of chlorine and vinylchloride, Akzo Nobel started a process for mixed PSW gasification. The process consists of two separate circulating fluid bed (CFB) reactors at atmospheric pressure (Figure 7). The first is a gasification reactor in which waste (usually rich with PVC) is converted at $700^{\circ} \mathrm{C}-900^{\circ} \mathrm{C}$ into product gas (fuel and $\mathrm{HCl}$ gas) and tars. The second unit is a combustion reactor that burns the residual tar to provide heat for the gasification process. Circulating sand between the gasifier and combustor transfers heat between the two reactors. Both reactors are of the riser type with a very short residence time. This type of reactor allows a high PVC waste throughput. If the input contains a lot of PE and PP, the output will contain a significant amount of propylene and ethylene [47].

\section{EXPERIMENTAL WORK}

\subsection{Feedstock Material}

As PSW samples, PET, PE, PP and PS were selected. They were either chopped into $1-2 \mathrm{~cm}$ long chips with maximum thickness below $0.5 \mathrm{~mm}$, or used as pellets of about 3 to $5 \mathrm{~mm}$.

\subsection{Fluidized Bed Gasification Reactor}

The gasification experiments were performed in a bubbling fluidized reactor. The experimental set-up is illustrated in Figure 8.

The bubbling fluidized bed is manufactured from Incoloy steel, and externally insulated. The air flow rate was controlled by flow meter. The heat-input from the electrical heater $(50 \mathrm{~kW})$ was set by the bed temperature. Vapours, gases and fluidization gas were exhausted by an induced draft fan, passing a water-cooled condenser and a liquid collection tank. Life steam $\left(110^{\circ} \mathrm{C}, 5\right.$ bar $)$ could be added in the windbox of the fluidized bed, i.e. below the distributor plate, built as a sintered metal plate with pressure drop of about $3000 \mathrm{~Pa}$ at the operating flow rate and temperature. 


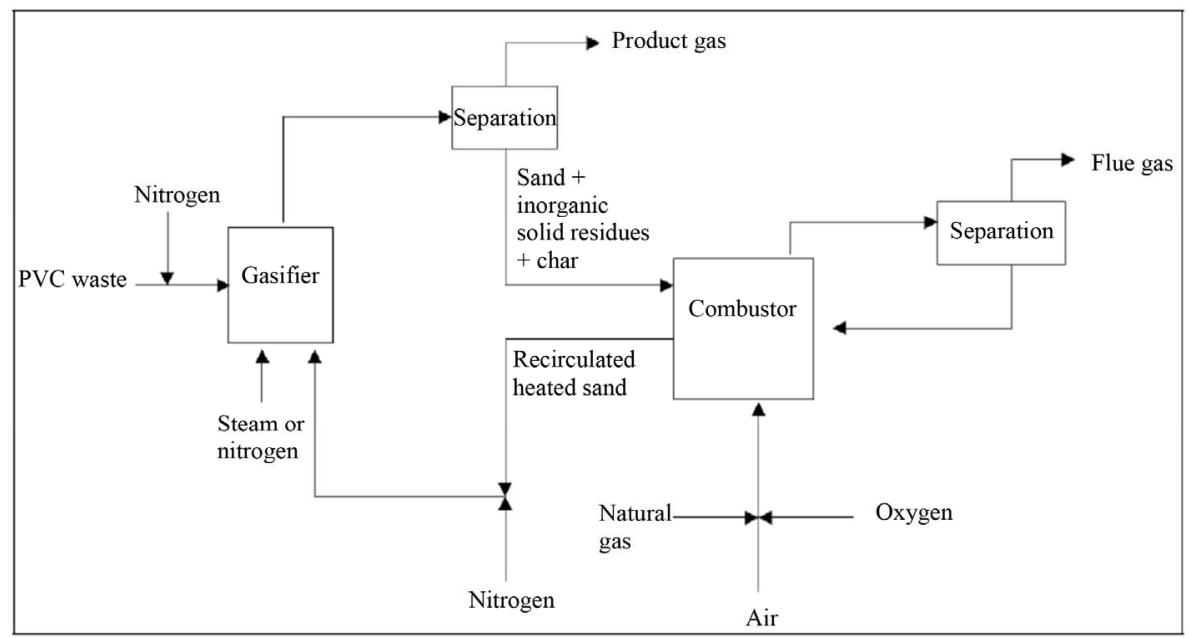

Figure 7. Akzo Nobel process schematic diagram [47].

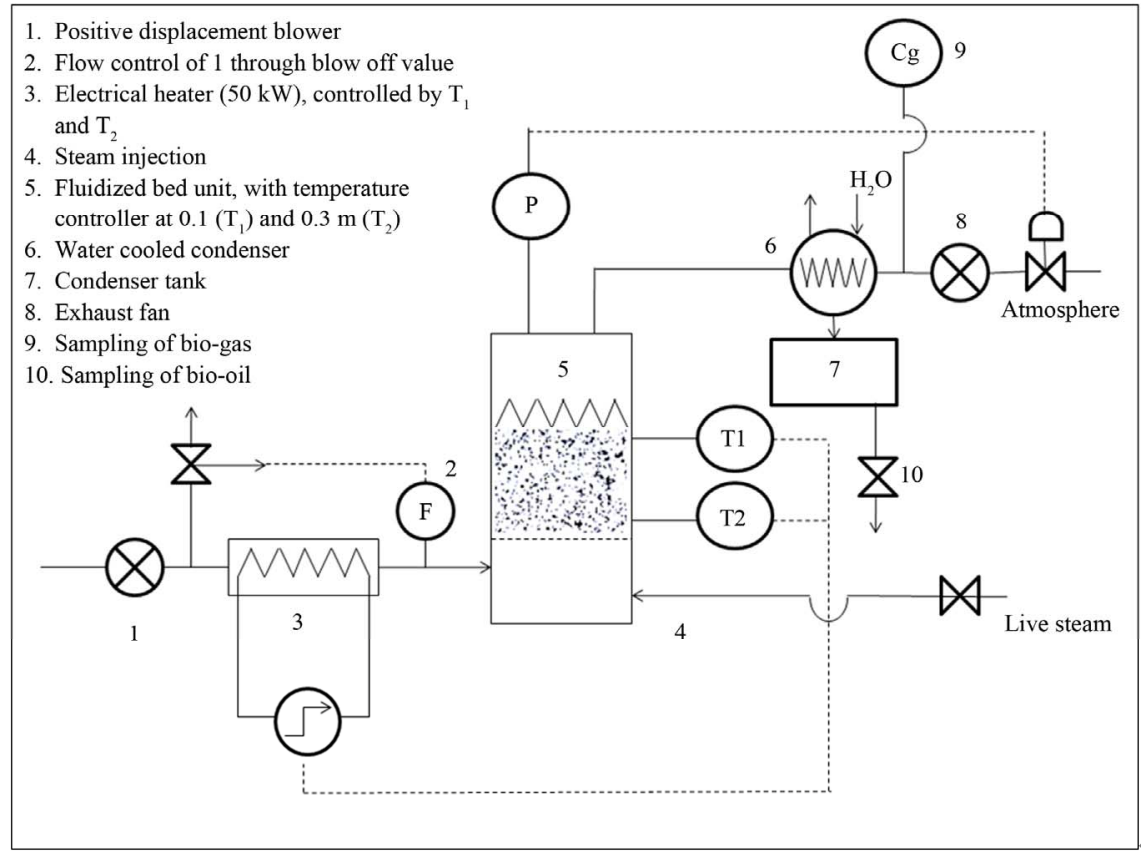

Figure 8. Schematic diagram of the gasification set-up.

The air flow rate was maintained at about $20 \%$ to $25 \%$ of the stoichiometric air flow needed for the combustion of each specific PSW material (Equivalence Factor, EF, $20 \%-25 \%$ ), and the velocity in the bed varied from 2 to 4 times the minimum fluidisation velocity, Umf. For some of the experiments, a steam dilution was also applied, reducing EF to below $15 \%$.

A known weight (between 0.3 and $0.5 \mathrm{~kg}$ ) of the PSW sample was placed into a perforated basket. The perforations enabled the fluidized bed sand to fluidize within the voidage of the PSW chips.

The fluidized bed consisted of about $15 \mathrm{~kg}$ of quartz sand $\left(150-300 \mu \mathrm{m}, 2600 \mathrm{~kg} / \mathrm{m}^{3}\right)$, for a total static bed height of about $35 \mathrm{~cm}$.
Gases were exhausted to the atmosphere, after appropriate analysis of $\mathrm{CO}, \mathrm{CO}_{2}, \mathrm{H}_{2}$ and $\mathrm{CH}_{4}$. Temperatures between $550^{\circ} \mathrm{C}$ and $800^{\circ} \mathrm{C}$ were tested.

In additional experiments, live-steam $\left(110^{\circ} \mathrm{C}, 5\right.$ bar $)$ was directly injected directly into the fluidization air flow, thus further reducing the partial pressure of $\mathrm{O}_{2}$ being present. All experiments were twice repeated under identical operating conditions, and average results were used to determine the kinetics of the PSW gasification.

The progress of the gasification reaction was monitored through the on-line measurement of the $\mathrm{CO}$ production. A first order gasification reaction was assumed to be valid, allowing the calculation of the reaction rate constants from PSW conversion as measured by $\mathrm{CO}$ 
production. The order of the reaction was determined by Brems et al. [7], and indeed found to be close to 1 for all polymers.

\subsection{Experimental Results}

The optimum temperatures of gasification (max. gas yield) are defined in Table 2, together with the activation energy, $E_{a}$, and the pre-exponential factor, $A$, of the Arrhenius kinetic expression.

The reaction rate constant, $k$, can be determined using the Arrhenius equation, reproduced below:

$$
k=A \mathrm{e}^{-E_{a} / R T}
$$

Using the experimental data, the reaction rate constant for the different PSW materials can be predicted at any temperature.

At the respective optimum T of PE, $k$ equals $5.35 \mathrm{~s}^{-1}$, representing a fast reaction rate.

The required residence time of $\mathrm{PE}$ in the reactor can be determined from the overall reaction kinetics, as given for a first order reaction:

$$
\frac{-\mathrm{d} W}{\mathrm{~d} t}=k W
$$

Integration of Eq.2 and introducing $X_{p}$, the degree of conversion (the weight percentage of initial solid that is successfully converted into the product), yields:

$$
-\ln \left(1-X_{p}\right)=k t
$$

From experimentation it was seen that the gasification of PSW is very efficient and a conversion factor, $X_{p}$, of 0.99 is easily achieved.

The required residence time, $t$, can then be evaluated as:

$$
-\ln (1-0.99)=5.35 t
$$

For the case of $\mathrm{PE}$, this leads to a required residence time, $t$, of $0.86 \mathrm{~s}$.

Gasification is hence a very fast reaction at the optimum temperatures, and ideally suited for a fluidised bed gasifier.

\section{CONCLUSIONS}

From the previous review and experimental work,

Table 2. Experimental values of $T, E_{a}$ and $A$.

\begin{tabular}{cccc}
\hline PSW & T (K) & $\boldsymbol{A}\left(\mathbf{s}^{-1}\right)$ & $\boldsymbol{E}_{\boldsymbol{a}}(\mathbf{k J} / \mathbf{m o l})$ \\
\hline PS & 953 & $2.94 \times 10^{14}$ & 212 \\
PET & 968 & $2.94 \times 10^{16}$ & 238 \\
PE & 1008 & $5.12 \times 10^{15}$ & 289 \\
PP & 1018 & $1.99 \times 10^{13}$ & 187 \\
\hline
\end{tabular}

the gasification of PSW can certainly be developed into a valid recycling route for PSW, producing a syngas, rich in $\mathrm{H}_{2}$ and $\mathrm{CO}$. Although references of industrial scale application are given in the literature, the future breakthrough of the process will require further experimental work to improve the equipment design and product optimisation. Advances in that area will aid in the improvement and more widespread use of gasification reactors.

\section{ACKNOWLEDGEMENTS}

The present research was supported by the Fundamental Research Funds for the Central Universities (Program RC1101).

\section{REFERENCES}

[1] Baeyens, J., Brems, A. and Dewil, R., (2010) Recovery and recycling of post-consumer waste materials-Part 2. Target wastes (glass beverage bottles, plastics, scrap metal and steel cans, end-of-life tyres, batteries and household hazardous waste). International Journal of Sustainable Engineering, 3, 232-245. doi:10.1080/19397038.2010.507885

[2] Al-Salem, S.M., Lettieri, P. and Baeyens, J. (2009) Recycling and recovery routes of plastic solid waste (PSW): A review. Waste Management, 29, 2625-2643. doi:10.1016/j.wasman.2009.06.004

[3] Al-Salem, S.M., Lettieri, P. and Baeyens, J., (2010) The valorization of plastic solid waste (PSW) by primary to quaternary routes: From re-use to energy and chemicals. Progress in Energy and Combustion Science, 36, 103-129. doi:10.1016/i.pecs.2009.09.001

[4] Ahrenfeldt, J. (2007) Characterisation of biomass producer gas as fuel for stationary gas engines in combined heat and power production. Ph.D. Thesis, Technical University of Denmark, Lyngby.

[5] Yoshioka, T., Gause, G., Eger, C., Kaminsky, W. and Okuwaki, A. (2004) Pyrolysis of polyethylene terephthalate in a fluidised bed plant. Polymer Degradation and Stability, 86, 499-504.

doi:10.1016/j.polymdegradstab.2004.06.001

[6] Smolders, K. and Baeyens, J. (2004) Thermal degradation of PMMA in fluidised beds. Waste Management, 24 849-857. doi:10.1016/j.wasman.2004.06.002

[7] Brems, A., Baeyens, J., Beerlandt, J. and Dewil, R. (2011) Thermogravimetric pyrolysis of waste polyethylene-terephthalate and polystyrene: A critical assessment of kinetics modeling. Resources, Conservation and Recycling, 55, 772-781. doi:10.1016/j.resconrec.2011.03.003

[8] Steiner, C., Kameda, O., Oshita, T. and Sato, T. (2002) EBARA's fluidized bed gasification: Atmospheric $2 \times$ $225 \mathrm{t} / \mathrm{d}$ for shredding residues recycling and two-stage pressurized $30 \mathrm{t} / \mathrm{d}$ for ammonia synthesis from waste plastics. Proceedings of Second International Symposium on Feedstock Recycle of Plastics and Other Innovative Plastics Recycling Techniques, Ostend, 8-11 September 2002. 
[9] Aguado, J., Serrano, D.P., Miguel, G.S., Escola, J.M. and Rodriguez, J.M. (2007) Catalytic activity of zeolitic and mesostructured catalysts in the cracking of pure and waste polyolefins. Journal of Analytical and Applied Pyrolysis, 78, 153-161. doi:10.1016/j.jaap.2006.06.004

[10] Mastellone, M.L. (1999) Thermal treatments of plastic wastes by means of fluidised bed reactors. Ph.D. Thesis, Second University of Naples, Naples.

[11] Arena, U. and Mastellone, M.L., (2006) Fluidized bed pyrolysis of plastic wastes. In: Scheirs, J. and Kaminsky, W., Eds., Feedstock Recycling and Pyrolysis of Plastic Wastes: Converting Waste Plastics into Diesel and Other Fuels, John Wiley \& Sons, Chichester. doi:10.1002/0470021543.ch16

[12] Scheirs, J. (1998) Polymer recycling. Wiley, New York.

[13] Vermeulen, I., Van Caneghem, J., Block, C., Baeyens, J. and Vandecasteele, C. (2011) Automotive shredder residue (ASR): Reviewing its productions from end-of-life vehicles (ELVs) and its recycling, energy and chemicals valorization. Journal of Hazardous Materials, 190, 8-27. doi:10.1016/i.jhazmat.2011.02.088

[14] Wallmann, P.H., Thorsness, C.B. and Winter, J.D. (1998) Hydrogen production from wastes. Energy, 23, 271-278. doi:10.1016/S0360-5442(97)00089-3

[15] Pinto, F., Franco, C., Andre, R.N., Miranda, M., Gulyurtlu, I. and Cabrita, I. (2002) Co-gasification study of biomass mixed with plastic wastes, Fuel, 81, 291-297. doi:10.1016/S0016-2361(01)00164-8

[16] VTT (2004) Power production from waste and biomass IV. Proceedings of the VTT Symposium, Finland, 8-10 April 2002.

[17] Buekens, A.G. (1978) Resource recovery and waste treatment in Japan. Resource Recovery and Conservation, 3, 275-306. doi:10.1016/0304-3967(78)90011-2

[18] Hasegawa, M., Fukuda, X. and Kunii, D. (1974) Gasification of solid waste in a fluidized bed with circulating sand. Conservation and Recycling, 3, 143-153. doi:10.1016/0361-3658(79)90004-3

[19] Borgianni, C., Filippis, P.D., Pochetti, F. and Paolucci, M. (2002) Gasification process of wastes containing PVC. Fuel, 14, 1872-1833.

[20] Xiao, G., Jin, B., Zhou, H., Zhong, Z. and Zhang, M. (2007) Air gasification of polypropylene plastic waste in fluidized bed gasifier. Energy Conversion and Management, 48, 778-786. doi:10.1016/j.enconman.2006.09.004

[21] Matsunami, J., Yoshida, S., Yokota, O., Neuzka, M., Tsuji, M. and Tamaura, Y. (1999) Gasification of waste tyre and plastic (PET) by solar thermochemical process for solar energy utilization. Solar Energy, 65, 21-23. doi:10.1016/S0038-092X(98)00085-1

[22] Pinto, F., Franco, C., Andre, R.N., Tavares, C., Dias, M. and Gulyurtlu, I. (2003) Effect of experimental conditions on co-gasification of coal, biomass and plastic wastes with air/steam mixture in a fluidized bed system. Fuel, 82, 1967-1976. doi:10.1016/S0016-2361(03)00160-1

[23] Slapak, M.J.P., Kasteren, J.M.N.V. and Drinkenburg, A.A.H. (2000) Design of a process fors team gasification of PVC waste. Resources, Conservation and Recycling, 30, 81-93.
doi:10.1016/S0921-3449(00)00047-1

[24] Xiao, G., Ni, M., Chi, Y., Jin, B., Xiao, R., Zhong, Z. and Huang, Y. (2009) Gasification characteristics of MSW and ANN prediction model. Waste Management, 29, 240244. doi:10.1016/j.wasman.2008.02.022

[25] Aznar, M.P., Caballero, M.A., Sancho, J.A. and Francs, E. (2006) Plastic waste elimination by co-gasification with coal and biomass in fluidized bed with air in pilot plant. Fuel Processing Technology, 87, 409-420. doi:10.1016/j.fuproc.2005.09.006

[26] Cozzani, V., Nicolella, C., Rovatti, M. and Tognotti, L., (1997) Influence of gas phase reactions on the product yields obtained in the pyrolysis of polyethylene. Industrial and Engineering Chemistry Research, 36, 342-348. doi:10.1021/ie950779z

[27] Stiles, H.N. and Kandiyoti, R. (1989) Secondary reactions of flash pyrolysis tars measured in a fluidized bed pyrolysis reactor with some novel design features. Fuel, 86, 275-282. doi:10.1016/0016-2361(89)90087-2

[28] Zolezzi, M., Nicolella, C., Ferrara, S., Iacobucci, C. and Rovatti, M. (2004) Conventional and fast pyrolysis of automotive shredder residues (ASR). Waste Management, 24, 691-699. doi:10.1016/j.wasman.2003.12.005

[29] Miscolczi, N., Bartha, L., Deák, G. and Jóver, B. (2004) Thermal degradation of municipal solid waste for production of fuel-like hydrocarbons. Polymer Degradation and Stability, 86, 357-366.

[30] Ciliz, N.K., Ekinci, E. and Snape, C.E. (2004) Pyrolysis of virgin and waste polyethylene and its mixtures with waste polyethylene and polystyrene. Waste Management, 2, 173-181. doi:10.1016/j.wasman.2003.06.002

[31] Ponzio, A., Kalisz, S. and Blasiak, W. (2006) Effect of operating conditions on tar and gas composition in high temperature air/steam gasification (HTAG) of plastic containing waste. Fuel Processing Technology, 3, 223-233. doi:10.1016/j.fuproc.2005.08.002

[32] Franco, C., Pinto, F., Gulyurtlu, I. and Cabrita, I. (2003) The study of reactions influencing the biomass gasification process. Fuel, 82, 835-842. doi:10.1016/S0016-2361(02)00313-7

[33] Marquez-Montesinos, F., Cordero, T., Rodriguez-Mirasol, J. and Rodriguez, J.J. (2002) $\mathrm{CO}_{2}$ and steam gasification of grapefruit skin char. Fuel, 81, 423-429. doi:10.1016/S0016-2361(01)00174-0

[34] Zanzi, R., Sjöström, K. and Björnbom, E. (1996) Rapid high-temperature pyrolysis of biomass in a free fall reactor. Fuel, 75, 545-550. doi:10.1016/0016-2361(95)00304-5

[35] Zanzi, R., Sjöström, K. and Björnbom, E. (2002) Rapid pyrolysis of agricultural residues at high temperature. Biomass and Bioenergy, 23, 357-366. doi:10.1016/S0961-9534(02)00061-2

[36] Narvaez, A., Orio A., Aznar, M.P. and Corella, J. (1996) Biomass gasification with air in an atmospheric bubbling fluidized bed: effect of six operational parameters. Industrial and Engineering Chemistry Research, 35, 21102120. doi:10.1021/ie9507540

[37] Harder, M.K. and Forton, O.T. (2007) A critical review of 
developments in the pyrolysis of automotive shredder residue. Journal of Analytical and Applied Pyrolysis, 79, 387-394. doi:10.1016/j.jaap.2006.12.015

[38] Mancini, G., Tamma, R. and Viotti, P. (2010) Thermal process of fluff: Preliminary test on a full scale treatment plant. Waste Management, 30, 1670-1682. doi:10.1016/j.wasman.2010.01.037

[39] Vigano, F., Consonni, S., Grosso, M. and Rigamonti, L., (2010) Material and energy recovery from automotive shredder residue (ASR) via sequential gasification and combustion. Waste Management, 30, 145-153. doi:10.1016/j.wasman.2009.06.009

[40] Cho, S.J., Jung, H.Y., Seo, Y.C. and Kim, W.H. (2010) Studies on gasification and melting characteristics of automotive shredder residue. Environmental Engineering Science, 27, 577-586. doi:10.1089/ees.2009.0389

[41] Lin, K.S., Chowdhury, S. and Wang, Z.P. (2010) Catalytic gasification of automotive shredder residues with hydrogen generation. Journal of Power Sources, 195, 60166023. doi:10.1016/j.jpowsour.2010.03.084

[42] Donaj, P., Yang, W., Blasiak, W. and Forsgren, C. (2010) Recycling of automotive shredder residue with a micro- wave pyrolysis combined with high temperature steam gasification, Journal of Hazardous Materials, 182, 80-89. doi:10.1016/j.jhazmat.2010.05.140

[43] Donaj, P., Blasiak, W., Yang, W. and Forsgren, C. (2011) Conversion of microwave pyrolysed ASR's char using high temperature agents. Journal of Hazardous Materials, 185, 472-481. doi:10.1016/j.jhazmat.2010.09.056

[44] WGT (2002) Waste gas technology energy from waste. http://www.wgtuk.com/ukindex.html

[45] Weissman, R. (1997) Recycling of mixed plastic waste by the Texaco gasification process. In: Hoyle, W. and Karsa, D.R., Eds., Chemical Aspects of Plastics Recycling, The Royal Society of Chemistry Information Services, Cambridge.

[46] Croezen, H. and Sas, H. (1997) Evaluation of the Texaco gasification process for treatment of mixed household waste. Final Report of Phase 1 and 2, CE, Delft, The Netherlands.

[47] Tukker, A., de Groot, H., Simons, L. and Wiegersma, S. (1999) Chemical recycling of plastic waste: PVC and other resins. European Commission, DG III, Final Report, STB-99-55 Final, Delft, The Netherlands. 